
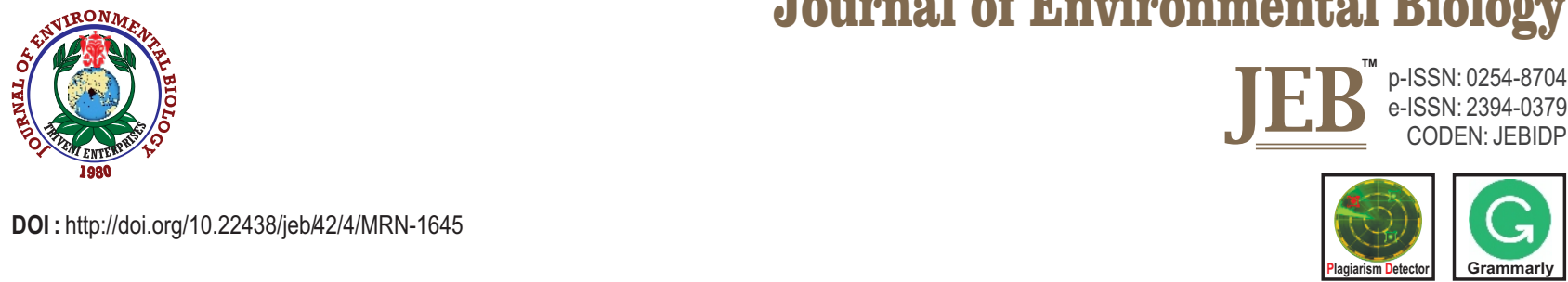

\title{
Production of an extracellular neutral protease by Bacillus aerius UB02 endophytic to carnivorous plant Utricularia stellaris
}

\author{
M. Chaudhuri', A.K. Paul' and A. Pal ${ }^{2 *}$ \\ 'Microbiology Laboratory, Department of Botany, University of Calcutta, Kolkata-700 019, India \\ ${ }^{2}$ Post Graduate Department of Botany, Serampore College, Hooghly-712 201, India \\ ${ }^{*}$ Corresponding Author Email : arundhatipalcu@gmail.com
}

\begin{abstract}
Aim: Endophytic bacteria indigenous to carnivorous plants have been explored for production of novel bioactive metabolites including extracellular enzymes. Bacillus aerius UB02, an extracellular neutral protease producing isolate endophytic to bladder of Utricularia stellaris L. f. was used in this study.

Methodology: The bacterial isolate UB02 was identified following morpholological, physiological, biochemical and 16S rRNA gene sequence analyses. The media as well as the cultural conditions for production of protease were optimized. The extracellular protease was isolated and purified from the cellfree culture filtrate by ammonium sulphate precipitation, dialysis and DEAE Sephadex ion exchange column chromatography and the optimum conditions for its activity were determined.
\end{abstract}

Results: The isolate Bacillus aerius UB02 (GenBank accession no. MK 696417, MCC accession no. 4132), produced significant amount of extracellular protease (38.29 $\mathrm{U} \mathrm{mg}^{-1}$ protein) during growth in casein supplemented synthetic medium. However, peptone yeast extract glucose medium appeared to be the best for the synthesis of enzyme. Production of enzyme was enhanced by the inoculum density of $1.5 \%$ (v/v), culture volume: flask volume (CVF) ratio of $1: 10$, substrate concentration of $2.5 \%$ (w/v) with temperature and $\mathrm{pH}$ adjusted at $37^{\circ} \mathrm{C}$ and 7.4 , respectively. Glucose $(2.2 \%$, w/v) and ammonium chloride $(1.2 \mathrm{~g} / \mathrm{L})$ as carbon and nitrogen sources also favoured the enzyme production. The neutral protease with a molecular weight of approximately $35 \mathrm{kDa}$ showed maximum activity at $40^{\circ} \mathrm{C}$, pH 7.8 with $2 \%(w / v)$ casein. The enzyme exhibited $\mathrm{K}_{\mathrm{m}}$ and $\mathrm{V}_{\text {max }}$ values of $6.81 \mathrm{mg} \mathrm{ml}^{-1}$ and $62.5 \mathrm{U} \mathrm{mg}^{-1}$ of protein, respectively, and was moderately thermostable. The protease activity was inhibited by $\mathrm{Pb}$ and $\mathrm{Cd}$ as well as 1,10 phenanthroline and $\beta$-mercaptoethanol.

Interpretation: These findings will help not only in understanding the role of endophytic bacteria and the enzymes produced by them in the digestion of prey by carnivorous plant but could also be explored for application in the field of biotechnology.

Key words: Bacillus aerius, Bacterial endophytes, Carnivorous plants, Enzyme kinetics, Extracellular protease, Utricularia stellaris

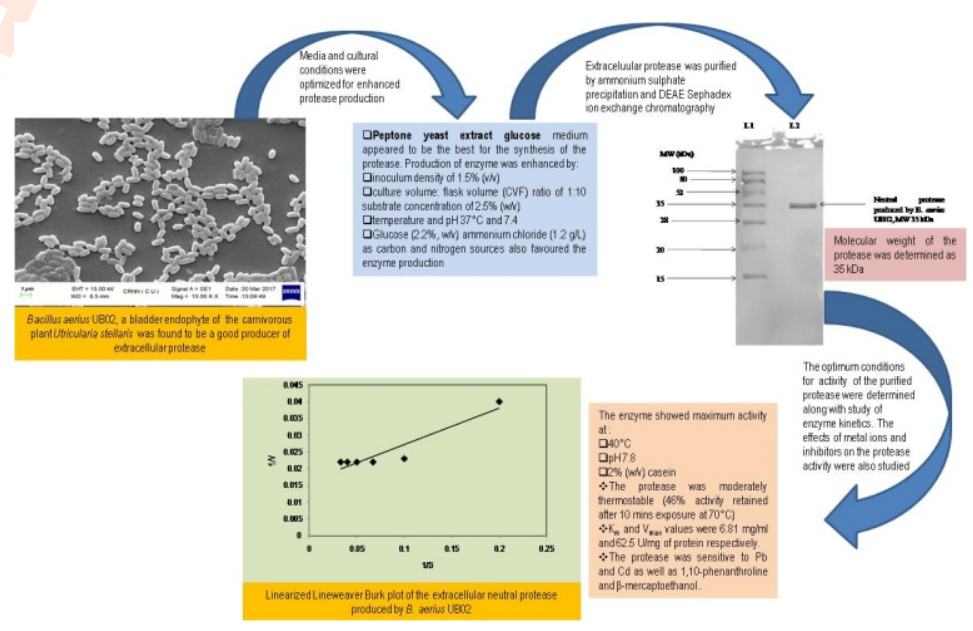

How to cite : Chaudhuri, M., A.K. Paul and A. Pal: Production of an extracellular neutral protease by Bacillus aerius UB02 endophytic to carnivorous plant Utricularia stellaris. J. Environ. Biol., 42, 955-963 (2021). 


\section{Introduction}

Exploitation of microbial enzymes in industrial sectors has widened the avenues for search of eco-friendly and sustainable bioprocesses (Banerjee and Ray, 2017; Razzaq et al., 2019). Interest of the scientific communities has been focussed towards production of novel enzymes with unique physiological properties and extreme environmental tolerance (Mienda and Yahya, 2011) to substantiate costly chemicals. Proteases are important hydrolytic enzymes utilized worldwide for breakdown of proteins and accounts for nearly $60 \%$ of the enzyme demand worldwide. Microbial proteases in particular play a pivotal role in food processing, processing of dairy products, preparation of pharmaceuticals, leather and textile industries (Gupta et al., 2002).

Proteolytic enzymes of microbial origin are essentially preferred over those of plant or animal proteases mainly due to rapid microbial growth rate, easy cultivation process, substrate specificity and effortless downstream processing for isolation and purification. Moreover, genetic manipulation of microorganisms often leads to alteration of enzymes desirable for industrial applications (Banerjee and Ray, 2017; Gupta et al., 2002). The presence of functional groups and position of peptide bonds that determine microbial proteases are classified as acidic $(\mathrm{pH} 3.8$ to 5.6), neutral ( $\mathrm{pH} 5$ to 8 ) and alkaline ( $\mathrm{pH} 9$ to 11) based on their optimal effectiveness in the reaction environment. Moreover, in microbes the intracellular proteases play a pivotal role in cellular differentiation, protein turnover and hormonal regulation, but the extracellular proteases find their application predominantly for protein hydrolysis (Adrio and Demain, 2014; Johnvesly and Naik, 2001; Razzaq et al., 2019).

Proteases, which are industrially important, are obtained from both bacterial as well as fungal sources, but majority of them are derived from strains belonging to the genus Bacillus (Pant et al., 2015; Elumalai et al., 2020). Screening of diverse groups of bacteria belonging to different environmental niches is a key factor towards isolating high yielding strains as well as identifying enzymes with unique properties. Several reports have established that the endophytic microbial community colonizing the internal tissues of plants produce a plethora of unique hydrolytic enzymes including proteases essential for their survival inside the plant environment (Zafaranloo et al., 2014; Mayerhofer et al., 2015; Ntabo et al., 2018; Castro et al., 2014; Ek-Ramos et al., 2019; Chu et al., 2019). Proteolytic activities have been recorded in bacteria associated with carnivorous species like Sarracenia (Scholtes and Kuserk, 2006) and Nepenthes (Li et al., 2012; Chan et al., 2016) that are likely to play beneficial role in digesting the prey and acquisition of nutrients for the host (Caravieri et al., 2014). Likewise, while assessing the metabolic potentials of bacteria endophytic to Drosera burmanii and Utricularia spp., production of significant amount of proteases (Chaudhuri et al., 2019) by $75 \%$ of the isolated strains has been already reported.

In this report, the isolation of a potent proteolytic endophytic bacterium Bacillus aerius UB02 from the bladder of $U$. stellaris L.f. has been studied and the cultural conditions for production of extracellular protease by this endophytic isolate have been optimized. Attempt has also been made to isolate and purify the extracellular protease elaborated by B. aerius UB02 and determine its characteristic features.

\section{Materials and Methods}

Bacterial culture and maintenance: The endophytic bacterium Bacillus UB02 obtained from the bladder of carnivorous plant Utricularia stellaris L.f. was used in this study. The endophytic isolate was maintained on slopes of nutrient agar by repeated sub-culturing.

Characterization and identification of the endophytic isolate: Morphological and physico-biochemical characteristics of Bacillus UB02 were determined following the standard microbiological methods (Gerhardt, 1994), while the antibiotic sensitivity was evaluated following the Kirby Bauer disc-diffusion method (Bauer et al., 1966). 16S rRNA gene sequence analysis was done by isolation of chromosomal DNA and purified according to the modified method of Murmur (1961).

PCR amplification was done using the universal primers 8F (5'-AGAGTTTGATCCTGGCTCAG-3') and 1492R (5'CGGTTACCTTGTTACGACTT-3'). Sequencing of the purified amplicon was carried out following Bi-directional DNA sequencing reaction using $B D T$ v3.1 Cycle sequencing kit on $A B I$ 3730 x I Genetic Analyzer. Consensus sequence of 16 S rDNA was obtained and compared with closely related neighbour sequences retrieved from the $\mathrm{NCBI}$ database using BLAST search. Phylogenetic analysis was carried out using the software package MEGA6 after obtaining multiple alignments of the data available from the public databases by ClustalW (Thompson et al., 1994). Bootstrap analysis was made using 1000 replicates.

Kinetics of growth and protease production: Growth associated protease production by Bacillus UB02 was determined in mineral salts medium (containing $\mathrm{gl}^{-1}: \mathrm{K}_{2} \mathrm{HPO}_{4}, 0.6$; $\mathrm{KH}_{2} \mathrm{PO}_{4}, 3 ; \mathrm{MgSO}_{4}, 0.1: \mathrm{NH}_{4} \mathrm{Cl}, 2 ; \mathrm{NaCl}, 0.5 ;$ glucose, 0.8; $\mathrm{pH}$ 7) supplemented with $1 \%(\mathrm{w} / \mathrm{v})$ casein. Erlenmeyer flasks were inoculated with overnight grown culture and incubated at $32^{\circ} \mathrm{C}$ under continuous shaking (120 rpm). Samples withdrawn at regular interval were assessed for growth and extracellular protease activity. Growth was measured by estimating the optical density at $540 \mathrm{~nm}$ and cell dry weight (CDW, $\left.\mathrm{g} \mathrm{l}^{-1}\right)$. Protease activity was assessed from cell-free culture filtrate following the method of Anson (1938).

Assay of protease activity: For determination of the protease activity, $200 \mu \mathrm{l}$ of cell-free culture filtrate was added to $500 \mu \mathrm{l}$ of 
$1 \%(\mathrm{w} / \mathrm{v})$ casein in $50 \mathrm{mM}$ phosphate buffer $(\mathrm{pH} 7)$, incubated at $40^{\circ} \mathrm{C}$ for $20 \mathrm{~min}$. The reaction was terminated by addition of $1 \mathrm{ml}$ of $10 \%$ (w/v) trichloroacetic acid (Anson, 1938). The residual substrate was quantified following the methods of Lowry et al. (1951) and Folin and Ciocalteau (1927) using tyrosine as the standard. One unit $(U)$ of protease is defined as the amount of enzyme that releases $1 \mu \mathrm{g}$ of tyrosine per $\mathrm{ml}$ per minute.

Total protein of cell-free culture filtrate was estimated according to Lowry et al. (1951) using bovine serum albumin (BSA) as standard. The total protease activity was divided by the amount of protein in the culture filtrate and expressed as specific activity of protease ( $\mathrm{U} \mathrm{mg}^{-1}$ of protein).

Optimization of conditions for production of protease: Cultural conditions involving growth media, inoculum concentration, aeration, temperature, $\mathrm{pH}$, substrate concentration, and carbon and nitrogen sources for the production of extracellular protease by Bacillus UB02 were optimized under batch cultivation.

Isolation and purification of bacterial protease: The isolate UB02 was allowed to grow in Davis Mingioli's medium under optimized cultural condition. The extracellular protease was isolated from cell-free culture filtrate and partially purified following the method of Secades and Guijarro (1999). Ammonium sulphate was gradually added to the supernatant (at $\left.4^{\circ} \mathrm{C}\right)$ in a stepwise manner to achieve $30-90 \%$ saturation. The protein thus precipitated is separated by centrifugation $(10,000 \mathrm{rpm}, 10 \mathrm{~min}$, $4^{\circ} \mathrm{C}$ ), pooled, dialysed in double distilled water at $4^{\circ} \mathrm{C}$ and dissolved in phosphate buffer $(\mathrm{pH} 7)$ for quatification of protease enzyme activity.

The dialysate was loaded to DEAE Sephadex column pre-equilibriated with phosphate buffer $(\mathrm{pH} 7)$ and the enzyme was eluted with the same buffer at a flow rate of $1 \mathrm{ml} \mathrm{min}^{-1}$. The purified protease was lyophilized at $-56^{\circ} \mathrm{C}$ (LSL Secfroid, SICO) and stored at $-20^{\circ} \mathrm{C}$ until further use.

Determination of properties of the purified bacterial protease: Molecular weight of the purified protease was determined using sodium dodecyl sulphate-polyacrylamide gel electrophoresis (SDS-PAGE) (Laemmli, 1970). Sample to be loaded in the well of SDS matrix was prepared by mixing purified protease with $10 \mathrm{mM}$ Tris $\mathrm{HCl}(\mathrm{pH} 8), 2.5 \%$ SDS, $5 \% \beta$ mercaptoethanol and $0.002 \%$ bromophenol blue. The gel was stained with Coomassie brilliant blue and protein bands were observed under transilluminator.

Effect of several factors such as temperature, $\mathrm{pH}$, substrate concentration, inhibitors and metal ions were studied with the partially purified protease.

Statistical analysis: All the experiments were performed in triplicates and the data shown represent the mean value \pm standard deviation (Altman and Bland, 2005).

\section{Results and Discussion}

The Gram-positive endospore forming motile rod-shaped endophytic bacterium isolated from the bladder of $U$. stellaris produced many enzymes like catalase, lipase, caseinase and gelatinase. It was able to ferment only glucose but could utilize galactose, sucrose, mannitol, sorbitol, fructose, arabinose, mannose and trehalose. The isolate UB02 was sensitive to penicillin G, ampicillin, ciprofloxacin, rifampicin, gentamycin, trimethoprim, vancomycin, tetracycline, kanamycin, and novobiocin. It was resistant to erythromycin and chlortetracycline (Table 1).

The 16S rDNA sequence (1579 bp) of Bacillus UB02 showed $100 \%$ sequence similarity with that of Bacillus aerius available in the NCBI databases and was designated as Bacillus aerius UB02. The nucleotide sequence of $16 \mathrm{~S}$ rRNAgene and the viable culture of Bacillus aerius UB02 were submitted to the GenBank database and to Microbial Culture Collection (MCC) Pune, India with the Accession numbers MK 696417 and MCC 4132 respectively.

The ability to produce hydrolytic enzymes, particularly protease, by bacteria endophytic to plants growing under diverse ecological conditions has been well documented (Carrim et al., 2006; Castro et al., 2014). Contrary to these, reports on the presence of proteolytic bacteria present in carnivorous plants, their involvement in protease secretion and digestion of prey are

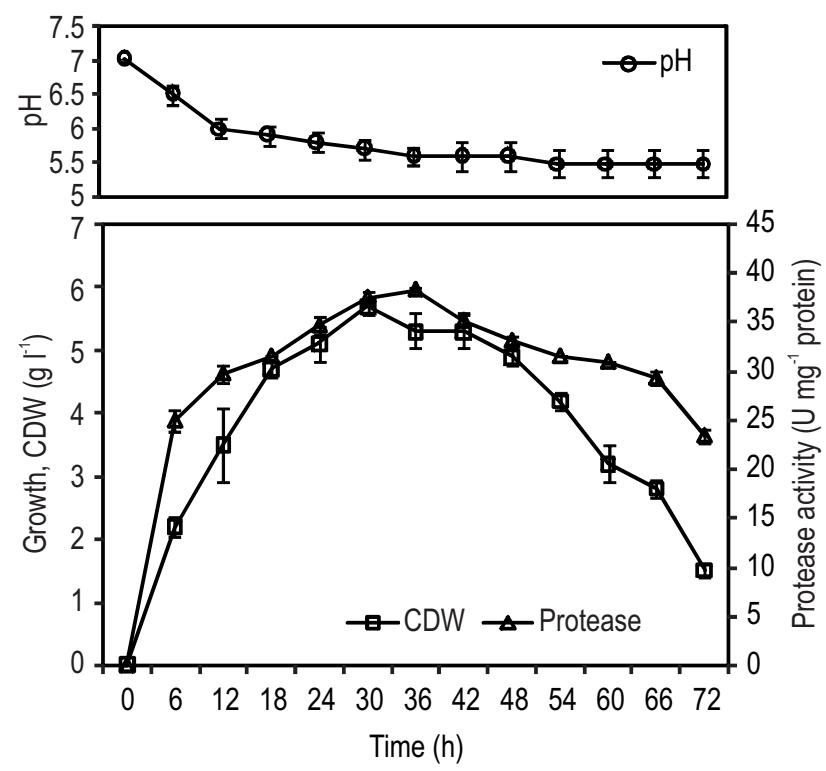

Fig. 1 : Time course of growth and protease production by $B$. aerius UB02 in casein supplemented mineral salts medium; $1 \mathrm{U}=$ amount of enzyme that releases $1 \mu \mathrm{g}$ of tyrosine per $\mathrm{ml}$ per min 
Table 1 : Morphological, physio-biochemical characters and antibiotic sensitivity profile of endophytic bacterial isolate Bacillus Ub02

\begin{tabular}{|c|c|c|c|c|}
\hline Character & Response & Character & Response & \\
\hline Colony morphology & Smooth, white & Fermentation and utilization of & Fermentation & Utilization \\
\hline Cell morphology & Single Rods, $2.5-3.7 \times 1.2-1.8 \mu \mathrm{m}$ & Glucose & + & + \\
\hline Gram nature & Gram +ve & Maltose & - & - \\
\hline Motility & + & Sucrose & - & + \\
\hline Endospore formation &,+ central & Mannitol & - & + \\
\hline Production of & & Sorbitol & - & + \\
\hline catalase & + & Fructose & - & + \\
\hline caseinase & + & Galactose & - & + \\
\hline oxidase & - & Lactose & - & - \\
\hline amylase & - & Rhamnose & - & - \\
\hline gelatinase & + & Raffinose & - & - \\
\hline pectinase & - & Arabinose & - & + \\
\hline urease & - & Aldonitol & - & - \\
\hline nitrate reductase & - & Dulcitol & - & - \\
\hline cellulase & - & Trehalose & - & + \\
\hline lipase & + & Inositol & - & - \\
\hline Indole production & + & Mannose & - & + \\
\hline Citrate utilization & + & Resistant to antibiotics & $\mathrm{E}, \mathrm{Ct}$ & \\
\hline Range of temp. for growth & $32-42^{\circ} \mathrm{C}$ & Sensitive to antibiotics & $\begin{array}{l}\text { Van, Tet, K, Nov, P, Amp, } \\
\text { Cip, Rif, Gen, Tri }\end{array}$ & \\
\hline Range of pH for growth & $7-9$ & & & \\
\hline $\mathrm{NaCl}$ tolerance & $5 \%(w / v)$ & & & \\
\hline
\end{tabular}

Antibiotics: $\mathrm{E}=$ erythromycin, $\mathrm{P}=$ penicillin $\mathrm{G}, \mathrm{Amp}=$ ampicillin, $\mathrm{Cip}=$ ciprofloxacin, Rif= rifampicin, Gen= gentamycin, Tri= trimethoprim, Van= vancomycin, Tet= tetracycline, $\mathrm{K}=$ kanamycin, $\mathrm{Ct}=$ chlortetracycline, Nov= novobiocin; + = positive and $-=$ negative response

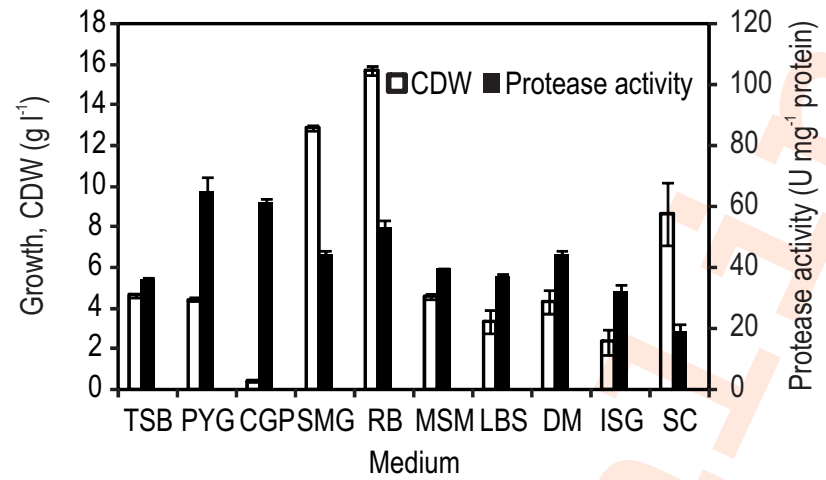

Fig. 2 : Effect of different culture media on growth and production of protease by $\mathrm{B}$. aerius UB02; $1 \mathrm{U}=$ amount of enzyme that releases $1 \mu \mathrm{g}$ of tyrosine per ml per min; Media used: TSB - tryptic soy broth, PYG peptone yeast extract glucose, CGP - casein hydrolysate glucose peptone, SMG - soyabean meal glucose, RB - rice bran urea medium, MSM - mineral salts medium, LBS - Lindenbein synthetic medium, DM Davis Mingiol's medium, ISG -inorganic salt glucose medium, SC - starch calcium carbonate medium

scanty (Takeuchi et al., 2011; Lee et al., 2014; Chaudhuri et al., 2017). This communication, as far as we are aware reports production and partial characterization of an extracellular protease by an endophytic Bacillus strain UB02 isolated from the bladders of $U$. stellaris (Chaudhuri et al., 2019) for the first time.
Members of the genus Bacillus, the most predominant amongst the endophytic community have been recognized as versatile metabolite producers (Reinhold-Hurek and Hurek, 2011; Frank et al., 2017; Ek-Ramos et al., 2019) which includes hydrolytic enzymes, especially proteases. The endogenous occurrence of Bacillus aerius has been reported by few authors in crop plants as well as halotolerant species where they play significant role as plant growth promoting endophytes as well as improvement of salt tolerance in plants (Arora et al., 2014). However, reports showing caseinolytic protease production by $B$. aerius is rare (Ananthanarayan and Dubhashi, 2015).

Time course of growth-associated production of extracellular protease by $B$. aerius UB02 in mineral salts medium containing $1 \%$ casein revealed accumulation of both biomass and protease (total activity $31.4 \mathrm{U} \mathrm{ml}^{-1}$ and specific activity $38.29 \mathrm{U} \mathrm{mg}$ ${ }^{1}$ protein) at $36 \mathrm{hr}$ of incubation which occurred at the end of log phase (Fig. 1). Following this, a decline was observed in both growth and protease production.

To determine a suitable medium for the maximum growth and production of protease, $B$. aerius UB02 was grown in different synthetic and complex media, each supplemented with $1 \%$ casein. Rice bran urea medium followed by soybean meal glucose medium were observed to be best suited for growth (CDW, $15.74 \mathrm{~g} \mathrm{l}^{-1}$ and $12.88 \mathrm{~g} \mathrm{l}^{-1}$ ), while peptone yeast extract 

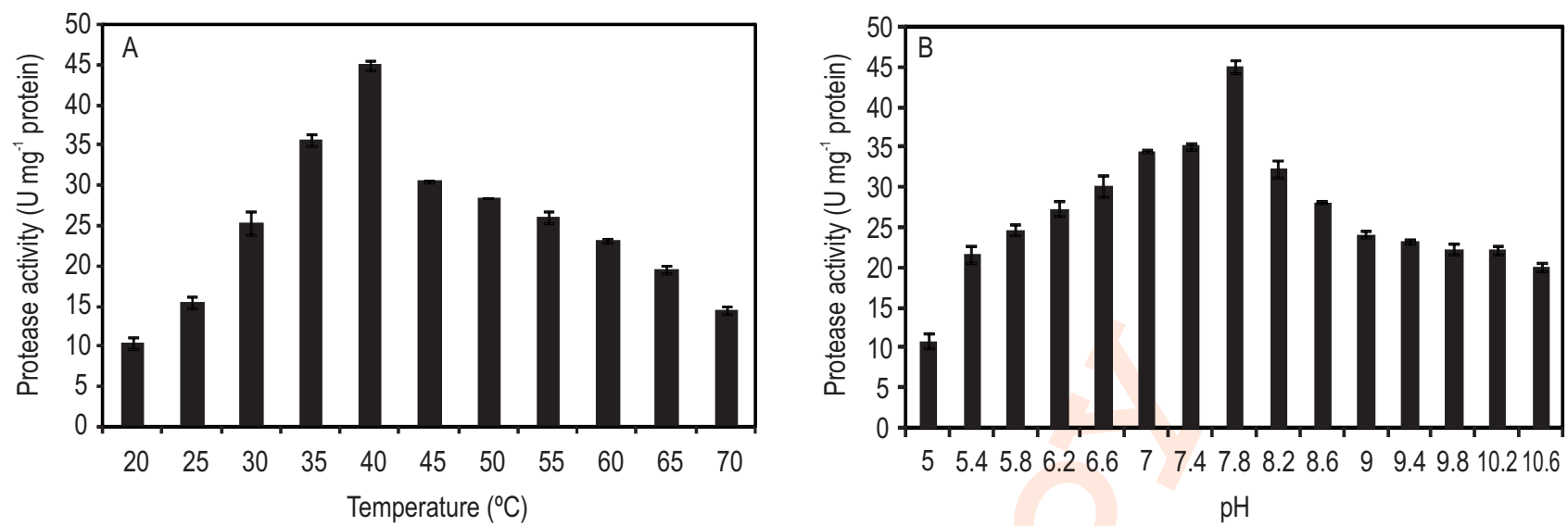

Fig. 3 : Effect of temperature $(A)$ and $\mathrm{pH}(\mathrm{B})$ on the activity of purified protease of $B$. aerius $U B 02 ; 1 \mathrm{U}=$ amount of enzyme that releases $1 \mu \mathrm{g}$ of tyrosine perml permin.

Table 2 : Optimization of cultural conditions for growth and production of protease by $B$. aerius UB02

\begin{tabular}{|c|c|c|c|c|}
\hline Parameters & Test range & Optimized parameter & Growth, CDW $\left(\mathrm{gl}^{-1}\right)$ & Protease (U mg ${ }^{-1}$ protein) \\
\hline Inoculum (\%, v/v) & $0.5-2$ & 1.5 & $4.6 \pm 0.14$ & $46.21 \pm 0.23$ \\
\hline Aeration (CVF) & $1: 10,1: 5,2: 5,3: 5,4: 5$ & $1: 10$ & $4.7 \pm 0.28$ & $47.52 \pm 0.9$ \\
\hline Temperature $\left({ }^{\circ} \mathrm{C}\right)$ & $28-42$ & 37 & $4.6 \pm 0.28$ & $47.49 \pm 1.18$ \\
\hline Casein $(\%, w / v)$ & $0.5-3$ & 2.5 & $4.7 \pm 0.28$ & $49.38 \pm 1.16$ \\
\hline $\mathrm{pH}$ & $5-10.6$ & 7.4 & $5.4 \pm 0.20$ & $48.19 \pm 0.59$ \\
\hline Carbon source & $\begin{array}{l}\text { glu, gal, suc, ara, fru, } \\
\text { tre, mannl, man, sor }\end{array}$ & Glucose & $4.6 \pm 0.28$ & $44.84 \pm 1.02$ \\
\hline Glucose $(\%, w / v)$ & $1.6-2.4$ & 2.2 & $4.85 \pm 0.06$ & $49.57 \pm 0.35$ \\
\hline Nitrogen source & $\begin{array}{l}\text { Peptone, tryptone, casamino } \\
\text { acid, yeast extract, } \mathrm{NH}_{4} \mathrm{Cl} \text {, } \\
\left(\mathrm{NH}_{4}\right)_{2} \mathrm{SO}_{4}, \mathrm{NaNO}_{3}, \mathrm{NH}_{4} \mathrm{NO}_{3}\end{array}$ & $\mathrm{NH}_{4} \mathrm{Cl}$ & $4.6 \pm 0.28$ & $49.02 \pm 0.56$ \\
\hline $\mathrm{NH}_{4} \mathrm{Cl}\left(\mathrm{gl}^{-1}\right)$ & $0.6-1.4$ & 1.2 & $5.7 \pm 0.06$ & $48.25 \pm 0.33$ \\
\hline
\end{tabular}

Values represent mean of triplicate experiments \pm standard deviation; $1 \mathrm{U}=$ amount of enzyme that releases $1 \mu \mathrm{g}$ of tyrosine per $\mathrm{ml}$ per min; CVF = culture volume by flask volume ratio; glu = glucose, gal = galactose, suc = sucrose, ara = arabinose, fru = fructose, tre- trehalose, sor= sorbitol, man= mannose, mann= mannitol
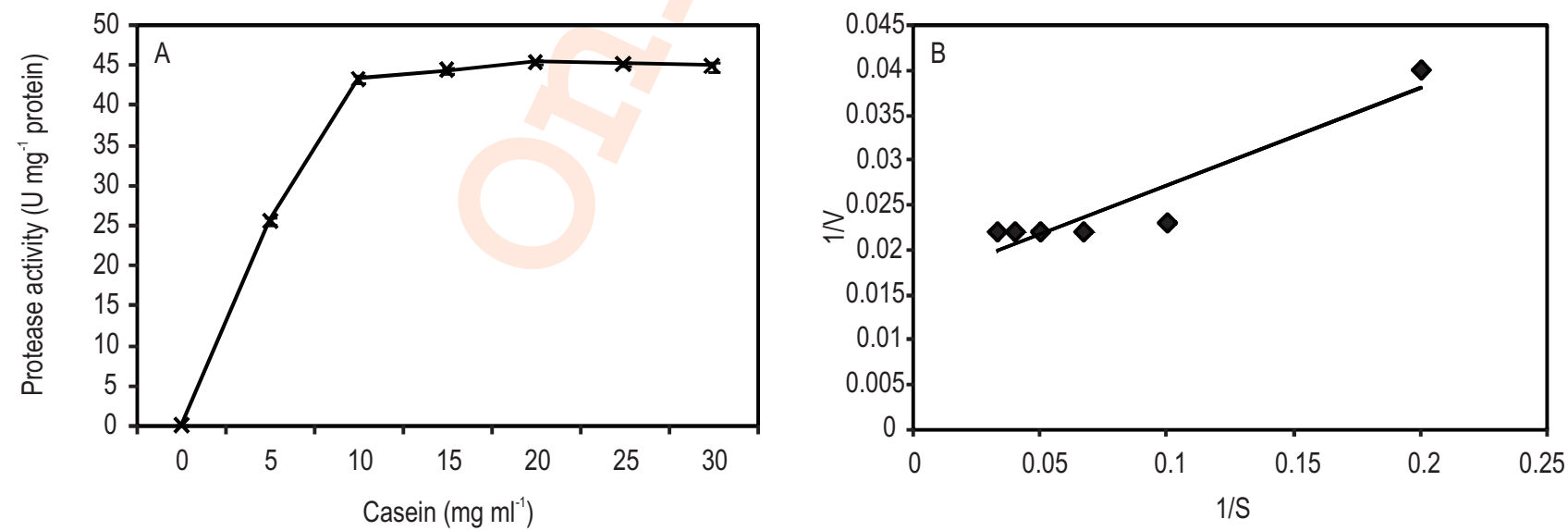

Fig. 4 : Effect of substrate concentration on the activity of protease produced by B. aerius UB02 (A) and linearized Lineweaver-Burk plot for enzyme activity (B); $1 \mathrm{U}=$ amount of enzyme that releases $1 \mu \mathrm{g}$ of tyrosine per $\mathrm{ml}$ per min. 
Table 3: Effect of different inhibitors on activity of the protease produced by $B$. aerius UB02

\begin{tabular}{llll}
\hline Inhibitor & Concentrations (mM) & Protease activity (U mg ${ }^{-1}$ protein) & \% inhibition \\
\hline Control & - & 44.11 & 0 \\
Ethylene diamine tetraacetic acid & 1 & 21.90 & 50.35 \\
& 2 & 18.39 & 58.26 \\
& 5 & 17.48 & 60.32 \\
$\beta$-mercaptoethanol & 10 & 15.73 & 64.29 \\
& 1 & 26.26 & 40.39 \\
& 2 & 25.21 & 42.77 \\
Phenyl methyl sulfonyl fluoride & 5 & 23.92 & 45.70 \\
& 10 & 21.06 & 52.39 \\
& 1 & 24.70 & 43.93 \\
1,10-phenanthroline & 2 & 22.36 & 49.24 \\
& 5 & 15.08 & 65.77 \\
& 10 & 10.72 & 75.67 \\
& 1 & 16.90 & 61.64 \\
\end{tabular}

$1 \mathrm{U}=$ amount of enzyme that releases $1 \mu \mathrm{g}$ of tyrosine per $\mathrm{ml}$ per $\mathrm{min}$

glucose and casein hydrolysate glucose peptone media were most favourable for production of protease by UB02 (specific activity of 65 and $44.13 \mathrm{U} \mathrm{mg}^{-1}$ protein, respectively) (Fig. 2).

Several other physico-chemical parameters influencing growth and protease production by $B$. aerius UB02 were also evaluated and the optimized conditions are summarized in Table 2. Both growth and production of extracellular protease was maximum at $1.5 \%$ inoculum concentration (46.21 $\mathrm{U} \mathrm{mg}^{-1}$ protein), culture volume by flask volume (CVF) ratio of $1: 10$ (47.52 $\mathrm{U} \mathrm{mg}^{-1}$ protein), a temperature of $37^{\circ} \mathrm{C}$ (47.49 $\mathrm{U} \mathrm{mg}^{-1}$ protein) and $\mathrm{pH}$ of 7.4 (48.19 $\mathrm{U} \mathrm{mg}^{-1}$ protein). Though growth of the isolate did not vary much above $1.5 \%$ casein, the highest protease activity (49.38 $\mathrm{U} \mathrm{mg}^{-1}$ protein) was recorded at $2.5 \%$ casein. Glucose $(2.2 \%)$ and ammonium chloride $\left(1.2 \mathrm{~g} \mathrm{l}^{-1}\right)$ appeared to be the best utilized carbon and nitrogen sources. The above studies revealed the dependence of $B$. aerius UB02 on nutritionally complex medium along with glucose and ammonium chloride as carbon and nitrogen sources, respectively. Moreover, the $\mathrm{pH}$ and temperature requirement indicated the mesophilic and neutrophilic nature of the producer organism.

The isolate $B$. aerius UB02 was cultured in Davis Mingioli's medium under optimized cultural conditions for $36 \mathrm{hr}$ and the extracellular protease was isolated from $500 \mathrm{ml}$ of cellfree culture filtrate following ammonium sulphate precipitation (30-90\% saturation). The maximum specific activity (44.11 U mg $\left.{ }^{1}\right)$ of the protease was found at $70 \%$ saturation level as compared to $38.29 \mathrm{U} \mathrm{mg}^{-1}$ of protein from the crude culture filtrate. The precipitates were pooled, dialysed and lyophilized as per the methods described. The partially purified enzyme was dissolved in $50 \mathrm{ml}$ of phosphate buffer and purified using DEAE Sephadex column chromatography.

The molecular weight of purified protease produced by $B$. aerius UB02 as detected using SDS-PAGE was approximately $35 \mathrm{kDa}$. Extracellular protease production has been reported from several species of Bacillus which have been categorized into two major types, alkaline protease and neutral protease, that have been reported to possess importance in food and detergent industries (Rani et al., 2012; Razzaq et al., 2019; Thomas et al., 2021). A thermostable neutral protease reported from $B$. stearothermophilus showed a molecular mass of $38 \mathrm{kDa}$ while that from B. subtilis showed a molecular weight of $65.4 \mathrm{kDa}$ in SDS-PAGE (Razzaq et al., 2019).

On evaluating the effect of temperature on protease activity in the range of $20^{\circ}-70^{\circ} \mathrm{C}$, activity was found to increase with increase in temperature and was maximum at $40^{\circ} \mathrm{C}(45.05 \mathrm{U}$ $\mathrm{mg}^{-1}$ protein). It was followed by a decline thereafter (Fig. 3A). Likewise, when the activity was tested in the $\mathrm{pH}$ range of 5.0-10.6 using citrate ( $\mathrm{pH}$ 5-6.2); phosphate (pH6.2-7.8); Tris- $\mathrm{HCl}$ (pH 7.88.6) and glycine- $\mathrm{NaOH}(\mathrm{pH} 8-10.6)$ buffers, the highest activity (44.96 U/mg of protein) was evident at $\mathrm{pH} 7.8$ (Fig. 3B). The protease so isolated from $B$. aerius UB02 in this present study appears to be a neutral protease. Reports suggest that these neutral proteases could be valuable in food industry, particularly due to the fact that they generate less bitterness in hydrolysing the proteinaceous componenets in food and have medium rate of 


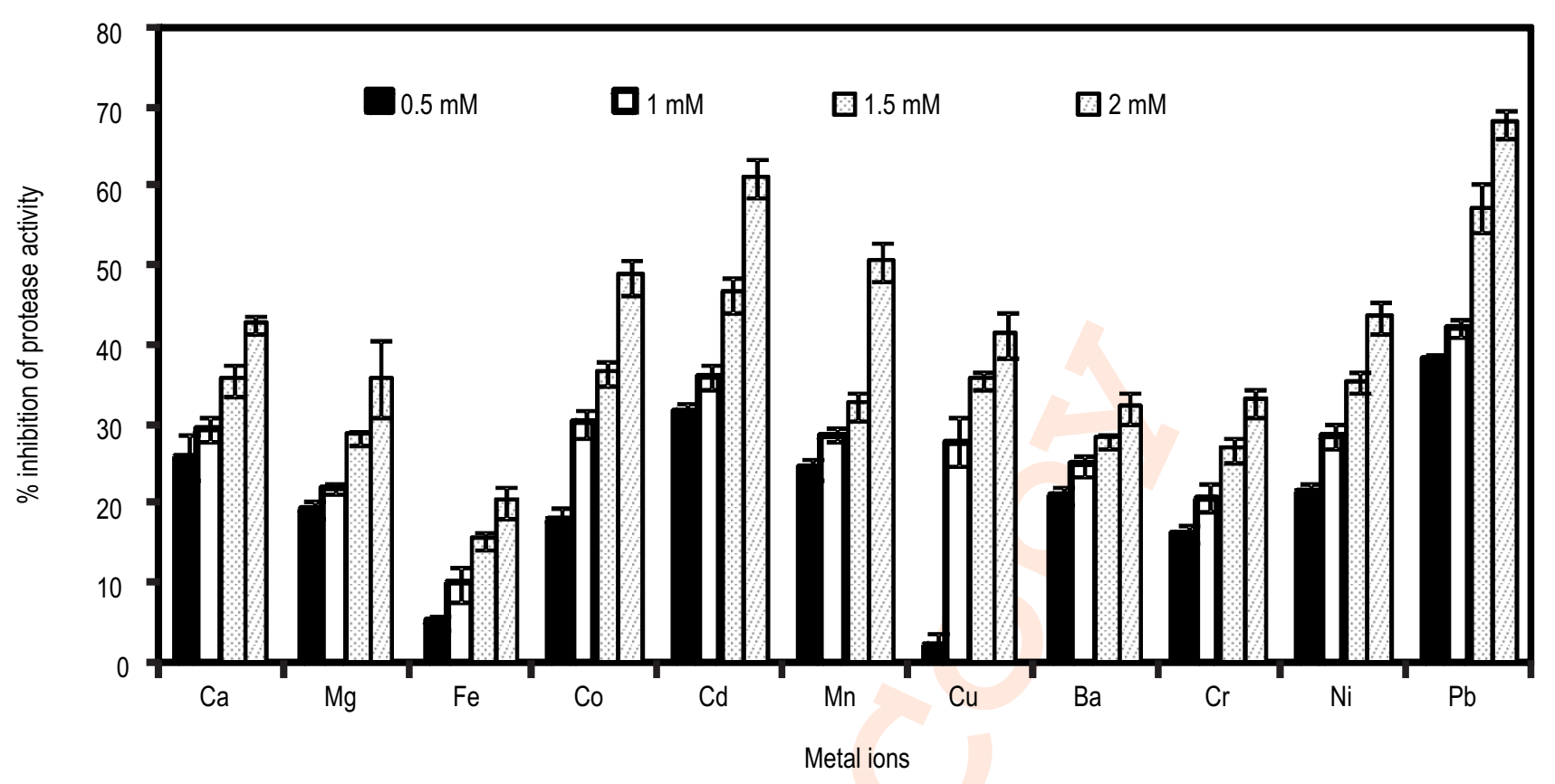

Fig. 5 : Effect of metal ions on the activity of protease produced by $B$. aerius UB02

reactions. They are also used in the brewing industry as they are insensitive to plant proteinase inhibitors (Razzaq et al., 2019).

Thermostability of protease in UB02 was studied by pretreatment at $40^{\circ} \mathrm{C}-70^{\circ} \mathrm{C}$ for $5-15$ min and subsequently tested for activity following the usual procedure. The protease activity declined with increase in temperature as well as duration of pretreatment. However, the enzyme retained nearly $52 \%$ and $46 \%$ of its activity when treated at $60^{\circ} \mathrm{C}$ and $70^{\circ} \mathrm{C}$ for $10 \mathrm{~min}$, respectively.

The specific activity of $B$. aerius UB02 protease increased with increasing concentrations of casein and the maximum activity (45.44U mg $^{-1}$ of protein) was observed at $2 \%(\mathrm{w} / \mathrm{v})$ casein showing a strong affinity towards the substrate (Fig. 4A). The enzyme kinetics followed a linearized Lineweaver-Burk plot (Fig. $4 B$ ) and the $\mathrm{K}_{\mathrm{m}}$ and $\mathrm{V}_{\max }$ of protease was $6.81 \mathrm{mg} \mathrm{ml}^{-1}$ and $62.5 \mathrm{U}$ $\mathrm{mg}^{-1}$ protein, respectively. The protease bears striking resemblance to neutral proteases produced by $B$. subtilis (Pant et al., 2015) and B. amyloliquefaciens (Wang et al., 2016).

Presence of different metal ions like $\mathrm{Ca}, \mathrm{Mg}, \mathrm{Fe}, \mathrm{Co}, \mathrm{Cd}$, $\mathrm{Mn}, \mathrm{Cu}, \mathrm{Ba}, \mathrm{Cr}, \mathrm{Ni}, \mathrm{Pb}(0.5-2 \mathrm{mM})$ as chloride salts inhibited the protease activity (Fig. 5). Pb was most inhibitory (68.25\%) at the highest concentration $(2 \mathrm{mM})$, while protease was least affected $(20.27 \%)$ by Fe. The effect of metals is in the following order: $\mathrm{Pb}>\mathrm{Cd}>\mathrm{Mn}>\mathrm{Co}>\mathrm{Ni}>\mathrm{Ca}>\mathrm{Cu}>\mathrm{Mg}>\mathrm{Cr}>\mathrm{Ba}>\mathrm{Fe}$ according to their degree of inhibition. The inhibition by heavy metal ions in general may be due to enzyme inactivation following their strong binding with sulphydryl groups (Mizrahi and Achituv, 1989).

Presence of EDTA, $\beta$-mercaptoethanol, PMSF and 1, 10phenanthroline in the reaction mixture inhibited the activity of protease of $B$. aerius UB02 (Table 3). The inhibition was maximum $(84.81 \%)$ at $10 \mathrm{mM} \mathrm{1,10-phenanthroline,} \mathrm{and} \mathrm{was}$ moderate in the presence of $\beta$-mercaptoethanol. Inhibition of proteolytic activity by 1,10 -phenanthroline (Table 3 ) also indicated its apparent similarity with the neutral protease secreted by B. subtilis (Feder etal., 1971).

The production and characterization of a neutral protease by endophytic Bacillus aerius UB02 having low thermotolerance property appears to be significant particularly in food industry for hydrolysis of food proteins and in brewing. The present study on the neutral protease produced by the bacterium $B$. aerius UB02 inherent of the bladder of $U$. stellaris, provides an indirect evidence in favour of the involvement of endogenous endophytic bacterial strains in prey digestion and host plants nutrition. However, detailed studies are warranted to justify and establish such involvement.

\section{Acknowledgments}

Financial assistance to Madhubanti Chaudhuri from University Grants Commission, New Delhi, India is duly acknowledged. We also express our sincere gratitude to Prof. G. G. Maiti, Department of Botany, University of Kalyani for collection and taxonomic identification of the plant material. 


\section{Add-on Information}

Authors' contribution: M. Chaudhuri: Performed experiments, wrote MS, A.K. Paul: Designed experiments, checked the MS, A. Pal: Analysed the results, checked MS, statistical analysis.

Research content: The research content of manuscript is original and has not been published elsewhere.

Ethical approval: Not applicable

Conflict of interest: The authors declare that there is no conflict of interest.

\section{Data from other sources: Not applicable}

Consent to publish: All authors agree to publish the paper in Journal of Environmental Biology.

\section{References}

Adrio, J. and A. Demain: Microbial enzymes: Tools for biotechnological processes. Biomolecules, 4, 117-139 (2014).

Altman, D. G. and L. M. Bland: Statistics Notes: Standard deviations and standard errors. BMJ (Clinical Research Edition), 331, 903 p. (2005). https://doi.org/10.1136/bmj.331.7521.903

Ananthanarayanan, L. and A. Dubhashi: Characterisation of Bacillus species isolated from natural sources for probiotic properties. Int. J. Curr. Biotechnol., 3, 22-27 (2015).

Anson, M.L.: The estimation of pepsin, trypsin, papain and cathepsin with haemoglobin. J. Gen. Physiol., 22, 79-89 (1938).

Arora, S., P.N. Patel, M.J. Vanza and G.G. Rao: Isolation and characterization of endophytic bacteria colonizing halophyte and other salt tolerant plant species from coastal Gujarat. Afr. J. Microbiol. Res., 8, 1779-1788 (2014).

Banerjee, G. and A.K. Ray: Impact of microbial proteases on biotechnological industries. Biotechnol. Genet. Eng. Rev., 33, 119-143 (2017).

Bauer, A.W., W.M. Kirby, J.C. Sherris and M. Turck: Antibiotic susceptibility testing by a standardized single disc method. Am. Clin. Pathol., 45, 493 (1966).

Caravieri, F.A., A.J. Ferreira, A. Ferreira, D. Clivati, V.F.O. de Miranda and W.L. Araujo: Bacterial community associated with traps of the carnivorous plants Utricularia hydrocarpa and Genlisea filiformis. Aquat. Bot., 116, 8-12 (2014).

Carrim, A.J.I., E.C. Barbola and J.D.G. Viera: Enzymatic activity of endophytic bacterial isolates of Jacaranda decurrens Cham. (Carobinha-do-campo). Braz. Arch. Bio.I Technol., 49, 353-359 (2006).

Castro, R.A., M.C. Quecine, P.T. Lacava, B.D. Batista, D.M. Luvizotto, J. Marcon, A. Ferreira, I.S. Melo and J.L. Azevedo: Isolation and enzyme bioprospection of endophytic bacteria associated with plants of Brazilian mangrove ecosystem. Springer Link., 3, 382 (2014).

Chan, X., K. Hong, W. Yin and K. Chan: Microbiome and biocatalytic bacteria in monkey cup (Nepenthes Pitcher) digestive fluid. Sci. Rep., 6, 1-10 (2016).

Chaudhuri, M., A. Pal and A.K. Paul: Proteolytic activity of Bacillus amyloliquefaciens UEF01 endophytic to carnivorous plant Utricularia exoleta R. Br. Biotechnol. J. Int., 17, 1-11 (2017).

Chaudhuri, M., A.K. Paul and A. Pal: Isolation and assessment of metabolic potentials of bacteria endophytic to carnivorous plants Drosera burmannii and Utricularia spp. Biosci. Biotechnol. Res. Asia, 16, 731-741 (2019).

Chu, Y., Y. Liu, T. Yao, Z. He, B. Lu and Y. Wang: Isolation, identification of a protease-producing endophytic bacteria and its culture conditions. J. Jian. Univ. Sci. Technol. (Natural Science Edition)., 1, 15(2019).

Ek-Ramos, M.J., R. Gomez-Flores, A.A. Orozco-Flores, C. RodrvguezPadilla, G. Gonzalez-Ochoa and P. Tamez-Guerra: Bioactive products from plant-endophytic Gram-positive bacteria. Front. Microbiol., 10, 463 (2019).

Elumalai, E.K., T.N.V.K.V. Prasad, J. Hemachandran, S.V. Therasa, T. Thirumalai and E. David: Extracellular synthesis of silver nanoparticles using leaves of Euphorbia hirta and their antibacterial activities. J. Pharm. Sci. Res., 2, 549-554 (2020).

Feder, J., L.R. Garrett and D. Kochavi: Studies on inhibition of neutral proteases by 1,10- phenanthroline. Biochimica et BiophysicaActa, 235, 370-377 (1971).

Folin, O. and V. Ciocalteau: On tyrosine and tryptophan determinations in proteins. J. Biol. Chem., 73, 627-650 (1927).

Frank. A., J. Saldierna-Guzman and J. Shay: Transmission of bacterial endophytes. Microorganisms, 5, E70 (2017).

Gerhardt, P.: In: Methods for General and Molecular Bacteriology. American Society for Microbiology, Washington D. C. (1994).

Gupta, R., Q.K. Beg and P. Lorenz: Bacterial alkaline proteases: Molecular approaches and industrial applications. Appl. Microbiol. Biotechnol., 59, 15-32 (2002).

Johnvesly, B. and G. Naik: Studies on production of thermostable alkaline protease from thermophilic and alkaliphilic Bacillus sp. JB99 in a chemically defined medium. Process Biochem., 37, 139-144 (2001).

Laemmli. U.K.: Cleavage of structural proteins during the assembly of the bead of Bacteriophage T4. Nature, 227, 680-685 (1970).

Lee, J.M., W.S. Tan and A.S.Y. Ting: Revealing the antimicrobial and enzymatic potentials of culturable fungal endophytes from tropical pitcher plants (Nepenthes spp.). Mycosphere, 5, 364-377 (2014).

Li, W., S. Li, J. Li, G. Ye, L. Zhu, X. Wang and Y. Liu: Isolation and identification of the protease producing endophyte bacteria from Nepenthes mirabilis. Acta Botan. Boreali-Occiden. Sini., 32, 2551$2555(2012)$.

Lowry, O.H., N.J. Rosenbrough, A.L. Farr and A. Randall: Protein measurement with the folin phenol reagent. J. Biol. Chem., 193, 265-275(1951).

Mayerhofer, M.S., E. Fraser and G. Kernaghan:Acid protease production in fungal root endophytes. Mycologia, 105, 1-11 (2015).

Mienda, B.S. and A. Yahya: Engineering of microbial proteases: Improving stability and catalytic performances. IIOABJ., 2, 10-15 (2011).

Mizrahi, L. and Y. Achituv: Effect of heavy metals ions on enzyme activity in the Mediterranean mussel, Donax trunculus. Bull. Environ. Contam. Tox., 42, 854-859 (1989).

Murmur, J.: A procedure for the isolation of deoxyribonucleic acid from micro-organisms. J. Mol. Biol., 3, 208-218 (1961).

Ntabo, R.M., A.K. Nyamache, W. Lwande, J. Kabii and J. Nonoh: Enzymatic activity of endophytic bacterial isolates from selected mangrove plants in Kenya. Open Microbiol. J., 12, 354-363 (2018). 
Pant, G., A. Prakash, J.V.P. Pavani, S. Bera, G.V.N.S. Deviram, A. Kumar, M. Panchpuri and R.G. Prasuna: Production, optimization and partial purification of protease from Bacillus subtilis. J. Taibah Univ. Sci., 9, 50-55 (2015).

Rani, K., R. Rana and S. Datt: Review on latest overview of protease. Int. J. Curr. Life Sci., 2, 12-18 (2012).

Razzaq, A., S. Shamsi, A. Ali, Q. Ali, M. Sajjad, A. Malik and M. Ashraf: Microbial proteases applications. Front. Bioengin. Biotechnol., 7, 1-20 (2019).

Reinhold-Hurek, B. and T. Hurek: Living inside plants: Bacterial endophytes. Curr. Opin. Plant Biol., 14, 435-443 (2011).

Scholtes, C.E. and F.T. Kuserk: Isolation and identification of proteolytic bacteria from leaves of the northern pitcher plant, Sarracenia purpurea. J. Pennsylvania. Sci., 80, 24-27 (2006).

Secades, P. and J.A. Guijarro: Purification and characterization of an extracellular protease from the fish pathogen Yersinia ruckeri and effect of culture conditions on production. Appl. Environ. Microbiol., 65, 3969-3975 (1999).

Takeuchi, Y., S. Chaffron, M.M. Salcher, R. Shimizu-Inatsugi, M.J.
Kobayashi, B. Diway, C. von Mering, J. Pernthaler and K.K. Shimizu: Bacterial diversity and composition in the fluid of pitcher plants of the genus Nepenthes. Syst. Appl. Microbiol., 38, 330-339 (2011).

Thompson, J.D., D.G. Higgins and T.J. Gibson: CLUSTAL W: Improving the sensitivity of progressive multiple sequence alignment through sequence weighting, position-specific gap penalties and weight matrix choice. NucleicAcid Res., 22, 4673-4680 (1994).

Thomas, N. N., Archana, V., Shibina, S. and B. T. Edwin: Isolation and characterization of a protease from Bacillus sps. Materials Today: Proceedings., 41, 685-691 (2021).

Wang, H., L. Yang, Y. Ping, Y. Bai, H. Luo, H. Huang and B. Yao: Engineering of a Bacillus amyloliquefaciens strain with high neutral protease producing capacity and optimization of its fermentation conditions. PLOS ONE., 11, 1-14 (2016).

Zaferanloo, B., T.B. Quang, S. Daumoo, M.M. Ghorbani, P.J. Mahon and E.A. Palombo: Optimization of protease production by endophytic fungus, Alternaria alternata, isolated from an Australian native plant. World J. Microbiol. Biotechnol., 30, 1755-1762 (2014). 